\title{
PIKKUKESKOSENA SYNTYNEIDEN LASTEN ELEIDEN JA ESINETOIMINTOJEN KEHITYS YKSIVUOTIAANA JA SEN YHTEYS KOGNITIIVISEEN KEHITYKSEEN KAKSIVUOTIAANA
}

\author{
Hannele Asumaniemi, Oulun yliopisto ja Coronaria \\ Kuntoutuspalvelut \\ Petriina Munck, Turun yliopistollinen keskussairaala \\ ja Helsingin yliopisto \\ Helena Lapinleimu, Turun yliopistollinen keskussairaala \\ ja Turun yliopisto \\ Suvi Stolt, Helsingin yliopisto
}

\begin{abstract}
Pikkukeskosena syntyneiden (syntynyt $<32$ raskausviikkoa ja/tai syntymäpaino $\leq 1500$ grammaa) lasten varhaista eleiden ja esinetoimintojen kehitystä on tutkittu vähän ja sen yhteyttä myöhempään kognitiiviseen kehitykseen ei ole tutkittu lainkaan, vaikka mahdollinen yhteys antaisi tärkeää erotusdiagnostista tietoa kliiniseen työhön. Tämän tutkimuksen tavoitteena oli saada lisää tietoa pikkukeskosena syntyneiden lasten eleiden kehityksestä sekä tarkastella ele-esinetoimintojen kehityksen ja kognitiivisen kehityksen välistä yhteyttä. Pikkukeskosten ( $N=57$ ) eleiden ja esinetoimintojen kehitystä arvioitiin Varhaisen kommunikaation ja kielen kehityksen arviointimenetelmällä (CDI) vuoden korjatussa iässä ja kognitiivista kehitystä Bayley Scales of Infant and Toddler Development -testin (Bayley-III) avulla kahden vuoden korjatussa iässä. Keskosten eleiden ja esinetoimintojen kehitys oli kokonaisuutena heikompaa kuin käytetyn menetelmän normiaineistossa. Kognitiivinen kehitys oli ryhmätasolla tarkastellen ikätasoista. Ele-esinetoimintojen ja kognitiivisen kehityksen välillä todettiin merkitsevä, positiivinen yhteys. Pikkukeskosena syntyneiden lasten varhaista kielellistä ja kommunikatiivista kehitystä tulisi seurata kliinisessä työssä, sillä se auttaa tunnistamaan varhain ne lapset, jotka tulevat mahdollisesti tarvitsemaan tukea kehitykseensä.
\end{abstract}

Avainsanat: eleiden kehitys, esinetoimintojen kehitys, hyvin ennenaikainen, hyvin pienipainoinen, keskonen, kognitiivinen kehitys, pikkukeskonen

Kirjoittajan yhteystiedot:

Hannele Asumaniemi

hannele.asumaniemi@coronaria.fi

\section{JOHDANTO}

Jo ensimmäisen ikävuoden aikana lapsilla on käytössään monenlaisia keinoja ilmaisuun (Sansavini ym., 2010). Ensimmäisen ikävuoden loppupuolella lapset alkavat käyttää 
erityisesti eleitä kommunikaatiossaan aktiivisesti. Kommunikoivalla eleellä tarkoitetaan ei-kielellistä käyttäytymistä, joka suunnataan toiseen ihmiseen jonkin tavoitteen saavuttamiseksi silloin, kun lapsella ei ole vielä sanoja käytössään (Guidetti \& Nicoladis, 2008; Laakso, 2003). Kommunikatiivinen ele tuotetaan tyypillisimmin joko käden tai pään liikkeillä, kuten osoittamalla, näyttämällä tai pään nyökyttelyllä ja pudistelulla (Laakso, 2003). Ensimmäisen ikävuoden lopulla lapset alkavat myös osoittaa tietävänsä, mitä tavallisilla esineillä tehdään. Nämä niin kutsutut esinetoiminnot (engl. recognitory gestures) ilmaantuvat lapselle noin vuoden iässä (Capone \& McGregor, 2004; Sansavini ym., 2010). Sekä eleet että niiden rinnalla kehittyvät esinetoiminnot edellyttävät kielen tapaan kognitiivisia taitoja, kuten kykyä kiinnittää huomiota ympäristön tapahtumiin, seurata niitä tarkkaavaisesti sekä toistaa mieleen painetut tapahtumat myöhemmin omatoimisesti (Capone \& McGregor, 2004; Iverson, 2010). Hyvin ennenaikaisena ja pienipainoisena syntyneet lapset ovat täysiaikaisina syntyneitä lapsia suuremmassa riskissä kognitiivisen kehityksen vaikeuksille (Bhutta ym., 2002; Bode ym., 2009; Munck ym., 2010; Ortiz-Mantilla ym., 2008; Toome ym., 2013). Tässä tutkimuksessa tarkastellaan pikkukeskosena (syntyneet $<32$ raskausviikkoa $\mathrm{ja} /$ tai syntymäpaino $\leq 1500$ grammaa) syntyneiden lasten varhaisten ele-esinetoimintojen kehitystä ja tämän kehityksen mahdollista yhteyttä lapsen myöhempään kognitiiviseen kehitykseen.

\section{Varhaisten ele- ja esinetoimintojen kehitys}

Tutkimusten mukaan lapsilla on käytössä noin 6-7 elettä jo yhteen ikävuoteen mennessä (Laakso, 2003; Stolt ym., 2014), ja eleiden käyttäminen on aktiivista toisen ikävuoden aikana (Capone \& McGregor, 2004; Gol-
din-Meadow, 2009). Niiden rooli kommunikaatiossa kuitenkin vähenee lapsen alkaessa kommunikoida puheen avulla yhä enenevässä määrin. Ajanjakson, joka alkaa lapsen ensimmäisen ikävuoden lopusta ja päättyy kahteen ikävuoteen, on havaittu olevan kriittinen eleiden ja esinetoimintojen ilmaantumiselle sekä symboliselle kehitykselle (Caprici ym., 2005; Sansavini ym., 2010). Deiktiset eleet (engl. deictic gestures), kuten näyttäminen, antaminen ja osoittaminen, ovat ensimmäisiä lapselle ilmaantuvia eleitä (Capone \& McGregor, 2004; Goldin-Meadow, 2009). Näitä eleitä voidaan kutsua myös esikielellisiksi, sillä ne ilmaantuvat ennen puhuttua kieltä ja kehittyvät ensimmäisen ikävuoden loppuun mennessä. Deiktisten eleiden ilmaantumisen aikaan myös lapsen kielellisen ymmärtämisen taidot ovat alkaneet kehittyä (Stolt ym., 2008; Suttora \& Salerni, 2012). Osoittamisele edeltää tavallisesti puhuttua sanaa (Goldin-Meadow, 2009) ja sen on havaittu ennakoivan lapsen varhaisen sanaston kehittymistä (Iverson \& Goldin-Meadow, 2005). Deiktisten eleiden rinnalla lapsi alkaa käyttää rituaalinomaisia pyytäviä eleitä (engl. ritualized request) noin 9-13 kuukauden iässä (Capone \& McGregor, 2004).

Esinetoiminnot (engl. recognitory gestures) ilmaantuvat lapselle noin vuoden iässä (Capone \& McGregor, 2004; Sansavini ym., 2010). Niiden avulla lapsi osoittaa tietävänsä, mitä tavallisilla esineillä tehdään. Näiden tunnistettavien toimintojen avulla lapsi voi siis jo tavallaan harjoitella nimeämistä, vaikkakin ilman sanoja (Iverson, 2010). Lapsi alkaa ensin jäljitellä sellaisia esinetoimintoja, joiden kohteena hän on itse hoivatoimissa (Laakso, 2003). Vähitellen lapselle ilmaantuvat myös aikuisten esinetoimintojen jäljittely, kuten puhelimessa puhuminen. Toiseen kohdistuvat esinetoiminnot ilmaantuvat tavallisesti toisella ikävuodella, siis hieman myöhemmin kuin itseen kohdistuvat esinetoiminnot. 
Esinetoimintojen on todettu olevan osoitus lapsen kyvykkyydestä symboliseen kuvailuun (Capone \& McGregor, 2004; Iverson, 2010).

Hieman esinetoimintojen ilmaantumisen jälkeen lapset alkavat tuottaa niin kutsuttuja esittäviä eleitä (engl. representational gestures), jotka muistuttavat viittomia, esimerkiksi käsien räpyttelyä viitaten lentävään lintuun (Capone \& McGregor, 2004). Esittävät eleet ilmaantuvat tavallisesti ennen 25 tuotetun sanan merkkipaalua (Acredolo \& Goodwyn, 1998; Capone \& McGregor, 2004). Lisäksi on olemassa kulttuuriin sidottuja niin sanottuja konventionaalisia eleitä (engl. conventional gestures), kuten käden vilkuttaminen merkkinä tervehdyksestä. Tällaiset eleet ilmaantuvat lapsen elevalikkoon toisen ikävuoden aikana.

Eleillä on eri tarkoituksia kielen kehityksen eri vaiheissa (Goldin-Meadow, 2009). Eleet tekevät mahdolliseksi lapsen ilmaisun silloin, kun aktiivinen ilmaistun sanaston kehitys ei ole vielä käynnistynyt. Lapsi voi käyttää varhaisia eleitä joko imperatiivisesti (esim. lapsi osoittaa haluamaansa esinettä) tai deklaratiivisesti (esim. lapsi haluaa jakaa huomion muiden kanssa; Guidetti \& Nicoladis, 2008). Lapsi saattaa erityisesti kehityksen varhaisvaiheessa myös tehostaa eleiden merkitystä ääntelyn avulla.

Keskosten eleiden ja esinetoimintojen kehityksestä on tehty vain muutamia tutkimuksia. Tutkimuksissa havaittiin, että keskoslapset omaksuivat eleitä vähemmän kuin täysiaikaisina syntyneet lapset, kun eleiden kehitystä seurattiin 0;9-2;0-vuotiaina (Ortiz-Mantilla ym., 2008; Sansavini ym., 2011; Stolt ym., 2014). Etenkin esinetoimintojen määrän havaittiin olevan vähäisempi keskosilla kuin verrokeilla ja erot esinetoimintojen kehityksessä kasvoivat keskosten ja verrokkilasten välillä iän myötä (Sansavini ym., 2011; Stolt ym., 2014). Mainituissa tutkimuksissa tutkittavien määrät olivat kuitenkin kohtuullisen pienet
(Ortiz.Mantilla ym., 2008; Stolt ym., 2014) tai tutkimuksessa käytettiin seulontamenetelmää, jolla saadaan varhaisten ele-esinetoimintojen kehityksestä vain suuntaa-antavaa tietoa (Sansavini ym., 2011). Keskosten varhaisten ele-esinetoimintojen kehitystä on siis tarpeen tutkia lisää aiempien löydösten vahvistamiseksi. Tutkimuksissa on myös havaittu, että keskosten kommunikatiivisessa ja kielellisessä kehityksessä on jatkuvuutta (Sansavini ym., 2011; Stolt ym., 2014; Stolt ym., 2016; Suttora \& Salerni, 2012). Esimerkiksi, viimeaikaisessa viiden vuoden mittaisessa seurannassa havaittiin, että ne hyvin pienenä keskosena syntyneet lapset, jotka olivat omaksuneet runsaasti varhaisia ele-esinetoimintoja 12 ja 15 kuukauden iässä, suoriutuivat parhaiten myös kielellisiä taitoja mittaavista testeistä viisivuotiaana (Stolt ym., 2016). Varhaisilla ele-esinetoiminnoilla vaikuttaa siis olevan merkitystä keskoslasten kielellisten ja kommunikatiivisten taitojen kehitystä tarkasteltaessa.

\section{Ele-ja esinetoimintojen ja kognitivisen kehityksen välinen ybteys}

Kognitiivisella kehityksellä tarkoitetaan erityisesti tiedollisten toimintojen, esimerkiksi havaintojen, ajattelun ja muistin, kehittymistä (Vohr, 2010). Täysiaikaisina syntyneiden lasten varhaisilla eleillä ja esinetoiminnoilla on havaittu olevan yhteyttä myöhempään kognitiiviseen kehitykseen (Laakso ym., 2011; Lyytinen, 1999). Varhaisen kommunikaation ja kielen kehityksen arviointimenetelmän normitutkimuksessa (Lyytinen, 1999) havaittiin, että lasten 14 kuukauden iässä arvioitu ele- ja esinetoimintojen hallinta oli merkitsevässä yhteydessä kognitiiviseen kehitykseen kaksivuotiaana (Bayley, 1993). Samoin nk. Esikko-menetelmän (Lapsen esikielellisen kommunikaation ja kielen ensikartoitus; Laakso, Eklund \& Poikkeus, 2011) 
normitutkimuksessa havaittiin tilastollisesti merkitsevä yhteys täysiaikaisina syntyneiden lasten varhaisten kommunikatiivisten taitojen ja myöhemmän kognitiivisen kehityksen välillä (Bayley-II). Lasten sosiaalisen kommunikaation muodot, kuten tunneilmaisu, katseen käyttö, kommunikaatio ja eleet, olivat 12-18 kuukauden iässä arvioituna merkitsevästi yhteydessä kognitiiviseen tasoon kahden ja kolmen vuoden iässä. Yhteydet olivat merkitsevimpiä, kun sosiaalisen kommunikaation taitoja arvioitiin noin puolentoista vuoden iässä. Myös esinetoiminnot, jotka lukeutuvat Esikko-menetelmässä nk. ymmärtämisen taitoihin, olivat yhdessä ymmärretyn kielen hallinnan kanssa yhden vuoden iästä lähtien merkitsevästi yhteydessä kognitiiviseen kehitykseen kaksi- ja kolmivuotiaana.

Hyvin ennenaikaisena ja pienipainoisena syntyneet lapset ovat täysiaikaisina syntyneitä lapsia suuremmassa riskissä kognitiivisen kehityksen vaikeuksille (Bhutta ym., 2002; Bode ym., 2009; Munck ym., 2010; Ortiz-Mantilla ym., 2008; Toome ym., 2013). Kognitiivisten kehityshäiriöiden riskin tiedetään kasvavan sitä suuremmaksi, mitä pienemmästä syntymäpainosta ja varhaisemmista syntymäviikoista on kyse (Foulder-Hughes \& Cooke, 2003). Pikkukeskosena syntyneiden lasten eleiden ja esinetoimintojen yhteyttä kognitiiviseen kehitykseen ei kuitenkaan ole tietääksemme aiemmin tutkittu, vaikka eleiden kehityksen varhainen arviointi voisi mahdollisesti antaa lisää ennakoivaa tietoa lapsen varhaisesta kehityksestä kliinisessä työssä. Koska eleet ja niiden rinnalla kehittyvät esinetoiminnot edellyttävät kielen tapaan kognitiivisia taitoja, kuten kykyä kiinnittää huomiota ympäristön tapahtumiin, seurata niitä tarkkaavaisesti sekä toistaa mieleen painetut tapahtumat myöhemmin omatoimisesti (Capone \& McGregor, 2004; Iverson, 2010) on mahdollista, että niiden varhainen kehitys ennakoi myös myö- hempää kognition kehitystä. Uuden tiedon myötä mahdollisiin ongelmiin pystyttäisiin puuttumaan varhain ja ennaltaehkäisemään vaikeuksien kasaantuminen. Heikosti kehittyvien lasten varhainen tunnistaminen on siis tärkeää.

Tämän tutkimuksen päätavoitteena oli: 1 . saada lisää tietoa nk. pikkukeskosena $(<32$. raskausviikkoa ja/tai syntymäpaino $\leq 1500$ grammaa) syntyneiden lasten varhaisten eleiden ja esinetoimintojen kehityksestä yhden vuoden korjatussa iässä sekä 2. tutkia tämän kehityksen yhteyttä myöhempään kognitiiviseen kehitykseen kahden vuoden korjatussa iässä. Korjatulla iällä viitataan ikään, joka lasketaan raskauden alkuvaiheessa määritetystä lasketusta ajasta (Blackmon ym., 2004).

Tämä tutkimus pohjaa Oulun yliopistossa tarkastettuun logopedian pro gradu työhön (Hirsikorpi, 2015). Tutkimus on osa Turun yliopistollisessa keskussairaalassa meneillään olevaa rekisteritutkimusta Hyvin ennenaikaisena ja/tai hyvin pienipainoisena syntyneiden lasten varhaisen reseptivivisen sanaston ja eleesinetoimintojen kehitys ja tämän kebityksen yhteys kognitiiviseen kehitykseen sekä kehitykseen vaikuttavat taustatekijät (vastuututkijat: Stolt \& Lapinleimu).

\section{TUTKITTAVAT JA MENETELMÄT}

\section{Tutkittavat lapset}

Tämän rekisteritutkimuksen aineisto on kerätty osana Turun yliopistollisen keskussairaalan keskosten kliinistä seurantaa ja se koostuu lasten 1 - ja 2-vuotistuloksista. Tutkimukseen otettiin mukaan ne lapset, jotka puhuivat äidinkielenään suomea ja joilta oli saatavilla kliinisessä työssä Varhaisen kommunikaation ja kielen kehityksen arviointimenetelmän ja Bayley-III -testin avulla kerätty aineisto. Tutkimuksessa oli mukana 57 hyvin ennenaikaisena (syntyneet $<32$ raskausviikkoa) ja/ 
tai hyvin pienipainoisena (syntymäpaino $\leq$ 1500 grammaa) syntynyttä lasta. Lapset olivat syntyneet vuosien 2007-2009 välisenä aikana. Tutkittavista oli poikia $68 \%(\mathrm{n}=38)$ ja tyttöjä $32 \%(n=18)$. Tieto yhden lapsen sukupuolesta puuttui. Lapset olivat syntyneet raskausviikoilla 24-35 (keskimääräinen gestaatioikä 29 viikkoa) ja heidän syntymäpainonsa vaihteli välillä 600-2120 grammaa (keskiarvo 1251 grammaa). Lapsista vajaalla 4 $\%: 1 l a(n=2)$ oli poikkeava löydös varhaisessa yhden kuukauden lasketussa iässä tehdyssä aivorungon kuuloherätevastetutkimuksessa (BAEP, brainstem auditory evoked potential) ja $19 \%: \operatorname{lta}(n=11)$ tieto BAEP mittauksesta puuttui. Tässä rekisteritutkimuksessa ei ollut verrokkiryhmää, vaan tutkittavien lasten tuloksia verrattiin arviointimenetelmien (Varhaisen kommunikaation ja kielen kehityksen arviointimenetelmä, Bayley-III -testi) normiaineistojen pisteisiin.

\section{Eleiden ja esinetoimintojen arviointi}

Eleitä ja esinetoimintoja arvioitiin vuoden korjatussa iässä The MacArthur Communicative Development Inventiories (CDI; Fenson ym., 1994) -menetelmän suomalaiseen aineistoon muokatun ja normitetun version avulla (Varhaisen kommunikaation ja kielen kehityksen arviointimenetelmä, Lyytinen, 1999). Tässä tutkimuksessa käytettiin menetelmän nuorempien lasten version (Lapsen kommunikaation kehitys: Sanat ja eleet) eleja esinetoimintojen kehitystä arvioivaa osiota (Toiminnat ja eleet). Osio koostuu 56 eleestä ja toiminnosta, jotka on luokiteltu seuraavasti: A. Ensimmäiset kommunikoivat eleet (10 elettä), B. Leikit (5 leikkitoimintaa), C. Toiminnat esineillä (16 esinetoimintoa), D. Leikkii vanhemmuuteen liittyviä toimintoja (13 leikkitoimintoa), E. Jäljittelee muita aikuisen toimintoja (11 toimintaa) ja F. Esineen korvaaminen leikissä (1). Osiossa A eleiden hallinta pisteytetään asteikolla $0-2$ (ei vielä käytä elettä 0 , käyttää joskus 1 p., käyttää usein 2 p.) ja osioissa B-F lapsi saa jokaisesta jo osaamastaan toiminnosta yhden pisteen. Tutkimuksessa eleet ja toiminnot jaoteltiin kehityksellisesti vielä Varhaisiin eleisiin (A ja B; yhteispistemäärä: 25 p.) sekä Myöhäisiin eleisiin (C, D, E ja F; yhteispistemäärä: 41 p.; Fenson ym., 2007). Toiminnat ja eleet -osion kaikkien osioiden yhteispistemäärä on 66 pistettä. CDI-menetelmän suomalaisen normiaineiston $(\mathrm{N}=95)$ pisteiden keskiarvo on vuoden iässä 29 pistettä (keskihajonta 8 p., vaihteluväli 14-54 pistettä; Lyytinen, 1999). Normiaineiston ( $\mathrm{N}=95)$ heikoimman $10 \%$ :n persentiilikäyrä (nk. huoliraja; vrt. Laakso, Eklund \& Poikkeus, 2011) on vuoden iässä 19 pisteen kohdalla (Lyytinen, 1999). Varhaisen kommunikaation ja kielen kehityksen arviointimenetelmä toimitettiin tutkimukseen osallistuneiden lasten vanhemmille postitse täytettäväksi ennen vuoden korjatun iän kehitysseurantapoliklinikkakäyntiä ja vanhemmat palauttivat täytetyt lomakkeet tullessaan sairaalaan vastasyntyneiden seurantapoliklinikalle.

\section{Kognitiivisen kehityksen arviointi}

Kognitiivisen kehityksen tasoa arvioitiin 2;0 vuoden korjatussa iässä Bayley-III -testin (Bayleys Scales on Infant and Toddler Development, Bayley, 2006; suom. versio Salonen, Munck \& Korja, 2008) kognitiivisella asteikolla. Testin kognitiivinen asteikko koostuu yleistä päättelyä mittaavista osioista, kuten informaation prosessointitaidoista, yhdistämis- ja erottelukyvystä, muistista, osa-kokonaisuuksien hahmottamisesta, leikistä ja numeerisesta hallinnasta. Bayley-III -testin normit pohjaavat yhdysvaltalaisen testiversion normeihin, jotka on tarkastettu suomalaisaineistossa. Testin standardipisteiden keskiarvo on 10 pistettä (keskihajonta 3 p., 
vaihteluväli $1-19$ p.). Bayleyn testin III-versio eroaa aiemmasta testin II-versiosta siten, että III-versiossa kielelliset osiot on eroteltu kognitiivista kehitystä arvioivasta osiosta omiksi osioikseen. Tässä työssä käytettiin vain testin kognitiivista osiota. Psykologi tutki lasten kognitiivisen kehityksen osana kliinistä seurantaa lapsen ollessa kahden vuoden korjatussa iässä.

\section{Analyysi}

Tutkimusaineistoa kuvattiin kuvailevien lukujen ja laatikkojana-kuvion avulla. OneSample T-testin avulla arvioitiin, erosiko tähän aineistoon kuuluvien pikkukeskosten CDI-menetelmän ele-esinetoimintojen osion kokonaispistemäärän ryhmätason keskiarvo vuoden korjatussa iässä CDI-menetelmän normiaineiston vastaavasta keskiarvosta. $\chi^{2}$ testillä arvioitiin, sisältyikö keskosaineistoon CDI-menetelmän normiaineistoa useammin sellaisia lapsia, joiden ele-esinetoimintoja mittaavan osion kokonaispistemäärä jäi nk. huolirajan alle (normiaineiston heikoimman $10 \%$ :n persentiiliarvo, < 19 pistettä).

Vuoden iän ele-esinetoimintojen ja kahden vuoden iän kognitiivisen kehityksen välisen yhteyden tutkimiseen käytettiin Pearsonin korrelaatiokerrointa. Varhaisen kommunikaation ja kielen kehityksen arviointimenetelmän ele-esinetoimintojen kehitystä kartoittavassa osiossa (Toiminnat ja eleet) huolirajan alittaneiden (< 19 pistettä) ja tyypillisesti kehittyneiden ( $\geq 19$ pistettä) keskosten myöhemmän kognitiivisen kehityksen välisiä eroja tutkittiin Mann-Whitney -testillä. Tutkittaessa, erosiko kognitiivisessa kehityksessään eri tavoin kehittyneiden lasten varhainen ele-esinetoimintojen hallinta vuotta aiemmin, käytettiin sen sijaan Kruskall-Walliksen -testiä ja parittaisiin vertailuihin Mann-Whitneyn U -testiä. Lapset jaettiin kolmeen alaryhmään kognitiivisen kehityk- sen perusteella tätä analyysia varten. Ryhmät olivat: normaali kognitiivinen kehitys kahden vuoden korjatussa iässä ( $\geq 8$ standardipistettä), lievä viive (5-7 standardipistettä, $-1 \mathrm{SD}$ ) ja merkittävä viive (1-4 standardipistettä, -2 SD). Ryhmät muokattiin Bayley-III -testin manuaalin (Salonen, Munck \& Korja, 2008) mukaisesti. Tilastollisen merkitsevyystason rajana oli $p<0.05$.

\section{TULOKSET}

Taulukossa 1 on esitetty erityyppisten eleiden ja esinetoimintojen kehitystä kuvailevat luvut eritellen. Luvuista on nähtävissä, että tässä tutkimuksessa keskiarvolapsi oli vuoden korjatussa iässä omaksunut kartoitettavista varhaisista kommunikoivista eleistä noin puolet (osio A) sekä muutamia menetelmän avulla kartoitettavista varhaisista leikkitoiminnoista (osio B). Esinetoiminnoista (itseen kohdistuvat esinetoiminnot; osio C) oli samoin omaksuttu noin puolet menetelmän avulla kartoitettavista toiminnosta. Sen sijaan muista menetelmän avulla kartoitettavista nk. myöhäisistä eleistä (osiot D - F; tavallisten esineiden tarkoituksenmukainen käyttö, vanhempien esinetoimintojen imitointi) oli omaksuttu vain muutamia.

Tutkimukseen osallistuneiden pikkukeskosten omaksumien eleiden ja esinetoimintojen kokonaispistemäärän keskiarvo oli 23 pistettä. Arvo oli $95 \%$ :n todennäköisyydellä merkitsevästi pienempi kuin CDI-menetelmän normiaineiston keskiarvo, $t=-6.05(56)$, $p<0,001$. Lasten taidoissa oli vuoden korjatussa iässä erittäin huomattavaa vaihtelua: Toiminnat ja Eleet -osion kokonaispisteet vaihtelivat välillä 7-43 pistettä. Nk. huolirajan alle (< 19 pistettä) sijoittui 19 keskosta (33\%), kun normiaineistossa vastaavan pistemäärän alapuolelle jää $10 \%$ aineistosta. Yli joka kolmannen pikkukeskosena syntyneen lapsen CDI-menetelmän ele-esinetoimintoja 
Taulukko 1. Pikkukeskosina syntyneiden lasteri $(N=57)$ ele- ja esinetoimintojen kehitys vuoden korjatussa iässä Varhaisen kommunikaation ja kielen kehityksen arviointimenetelmän Toiminnat ja Eleet -osion avulla arvioituna.

\begin{tabular}{|l|l|l|l|l|l|}
\hline & Keskiarvo & Keskihajonta & Mediaani & Minimi & Maksimi \\
\hline Varhaiset eleet & 11 & 4 & 11 & 2 & 17 \\
\hline $\begin{array}{l}\text { A. Ensimmäiset } \\
\text { kommunikoivat eleet }\end{array}$ & 9 & 3 & 9 & 2 & 14 \\
\hline B. Leikit & 2 & 1 & 2 & 0 & 5 \\
\hline Myöhäiset eleet & 12 & 6 & 10 & 4 & 27 \\
\hline C. Toiminnat esineillä & 7 & 3 & 6 & 2 & 15 \\
\hline $\begin{array}{l}\text { D. Leikkii vanhemmunteen } \\
\text { liittyviä toimintoja }\end{array}$ & 1 & 2 & 1 & 0 & 7 \\
\hline $\begin{array}{l}\text { E. Jäljittelee muita } \\
\text { aikuisten toimintoja }\end{array}$ & 3 & 2 & 3 & 0 & 10 \\
\hline $\begin{array}{l}\text { F. Esineiden } \\
\text { korvaaminen leikissä }\end{array}$ & 0 & 0 & 0 & 0 & 1 \\
\hline Kokonaispistemäärä & 23 & 8 & 22 & 7 & 43 \\
\hline
\end{tabular}

mittaavan osion kokonaispistemäärä oli siis vuoden korjatussa iässä < 19, kun verrokkiaineistossa joka kymmenes lapsi sai vastaavan arvon. Prosentuaalisten osuuksien ero oli tilastollisesti erittäin merkitsevä, $\chi^{2}=31,48(1)$, $p<0,001$.

Tutkimukseen osallistuneiden pikkukeskosten Bayley-III -testistä saatu kognitiivisen kehityksen keskiarvo oli 10 standardipistettä, joka vastaa ikäryhmän keskiarvoa (Taulukko 2). Suurimmalla osalla keskosista eli $88 \%$ :lla $(\mathrm{n}=50)$ kognitiivinen suoriutuminen sijoittui normaalille tasolle ( $>7$ standardipistettä). Kognitiivisessa kehityksessä havaittiin kuitenkin myös huomattavaa vaihtelua lasten välillä. Lievää viivettä havaittiin $7 \%$ :lla $(\mathrm{n}=$ 4) keskosista ja merkittävää viivettä $5 \%$ :lla (n =3) keskosista.

Pikkukeskosten eleiden ja esinetoimintojen (CDI) ja kognitiivisen kehitystason (BayleyIII) väliset korrelaatiokertoimet, niiden selitysosuudet sekä merkitsevyystasot on esitetty Taulukossa 3. Keskosten vuoden korjatussa iässä mitattujen kaikkien ele- ja esinetoimintojen kokonaispistemäärän ja kahden vuoden korjatussa iässä mitatun kognitiivisen tason välillä oli kohtuullinen, tilastollisesti merkitsevä yhteys $(r=0,37, p=0,004)$. Varhaiset ja

Taulukko 2. Pikkukeskosina syntyneiden lasten kognitiivinen kehitys 2;0 vuoden korjatussa iässä Bayley-III -testillä arvioituna. Taulukossa ilmoitetut luvut pohjaavat standardipisteisiin.

\begin{tabular}{|l|l|l|l|l|l|}
\hline & Keskiarvo & Keskihajonta & Mediaani & Minimi & Maksimi \\
\hline Kognitiivinen kehitys & 10 & 3 & 11 & 3 & 15 \\
\hline
\end{tabular}


Taulukko 3. Vuoden iän ele-esinetoimintojen ja kahden vuoden iän kognitiivisen kehityksen väliset yhteydet pikkukeskosilla $(\mathrm{N}=57)$. Taulukossa ilmoitetaan Pearsonin korrelaatiokertoimet $(r)$, niiden selitysosuus sekä yhteyksien merkitsevyystasot $(p)$. Merkitsevät $p$-arvot on tummennettu.

\begin{tabular}{|l|l|l|l|}
\hline \multicolumn{2}{|c}{$r$} & \multicolumn{2}{c}{ Kognitiivinen kehitys } \\
\hline Varhaiset eleet & 0,32 & 0,10 & $\mathbf{0 , 0 1 5}$ \\
\hline A. Ensimmäiset kommunikoivat eleet & 0,30 & 0,09 & $\mathbf{0 , 0 2 2}$ \\
\hline B. Leikit & 0,22 & 0,05 & 0,103 \\
\hline Myöhäiset eleet & 0,32 & 0,10 & $\mathbf{0 , 0 1 5}$ \\
\hline C. Toiminnat esineillä & 0,34 & 0,12 & $\mathbf{0 , 0 1 0}$ \\
\hline D. Leikkii vanhemmuuteen liittyviä toimintoja & 0,18 & 0,03 & 0,181 \\
\hline E. Jäljittelee muita aikuisen toimintoja & 0,23 & 0,05 & 0,081 \\
\hline F. Esineiden korvaaminen leikissä & 0,14 & 0,02 & 0,314 \\
\hline Kokonaispistemäärä & 0,37 & 0,14 & $\mathbf{0 , 0 0 4}$ \\
\hline
\end{tabular}

myöhäiset eleet korreloivat molemmat kohtuullisesti ja tilastollisesti merkitsevästi lapsen kognitiivisen kehityksen tasoon (varhaiset: $r$ $=0,32, p=0,015$; myöhäiset: $r=0,32, p=$ $0,015)$, vaikkakin yhteyksien havaittiin olevan hieman heikompia kuin kaikkien eleiden kokonaispistemäärän. Tarkastellessa yksittäisiä CDI-menetelmän osioita huomattiin, että ainoastaan Ensimmäiset kommunikoivat eleet (osio A) ja Toiminnat esineillä (osio C) olivat tilastollisesti merkitsevästi yhteydessä lapsen myöhempää kognitiiviseen kehitykseen.

Tutkittaessa, eroavatko CDI-menetelmän avulla arvioitujen, Eleet ja toiminnot -osion kokonaispisteiden perusteella huolirajan alle (< 19 pistettä) jääneiden keskosten ja tyypillisesti kehittyneiden keskosten myöhempi kognitiivinen kehitys toisistaan todettiin, ettei ryhmien välillä ilmennyt tilastollisesti merkitsevää eroa kahden vuoden korjatussa iässä $(U=334,0, p=0,645)$.

Tarkasteltaessa, erosiko pikkukeskosten varhainen ele-esinetoimintojen kehitys eri tavoin kognitiivisessa kehityksessään (tyypillinen kehitys, lievä viive, merkittävä viive) edenneiden lasten ryhmissä, havaittiin ryhmien välillä tilastollisesti merkitsevä ero $\left(\chi^{2}=8,8\right.$, $p=0,013$; Kuvio 1). Testattaessa tarkemmin minkä ryhmien välillä ero oli, varhaisen eleesinetoimintojen kehityksen todettiin eroavan kognitiiviselta kehitykseltään normaalisti edenneiden ja kognitiiviselta kehitykseltään merkittävän viiveen ryhmään kuuluvien lasten välillä $(U=-28,35, p=0,012)$. Muiden ryhmien välillä ei ollut tilastollisesti merkitseviä eroja. Tulokset noudattavat trendiä, jonka mukaan kognitiivisessa suoriutumisessa heikoimmin edenneet keskoset olivat omaksuneet myös varhaisia eleitä ja esinetoimintoja heikoiten. Ne keskoslapset, jotka olivat kaksivuotiaana kehittyneet kognitiivisesti normaalisti (> 7 SP, $\mathrm{n}=50$ ), olivat omaksuneet vuoden korjatussa iässä myös varhaisia eleitä ja esinetoimintoja eniten (ryhmän Toiminnat ja Eleet -osion keskiarvo, ka: 24 pistettä, keskihajonta, kh 8, vaihteluväli, vv: 10-43). Kognitiiviselta kehitykseltään lievän viiveen 
Kuvio 1. Laatikko-jana -kuvio vuoden iän ele-esinetoimintojen ja kahden vuoden iän kognitiivisen kehityksen välisestä yhteydestä pikkukeskosilla $(N=57)$. Kognitiivista kehitystä kuvaavat ryhmät ovat: normaali kehitys ( $\geq 8$ standardipistettä, SP, $n=50$ ), lievä viive (5-7 SP, -1 SD, n=4) ja merkittävä viive (1-4 SP, $-2 \mathrm{SD}, \mathrm{n}=3$ ).

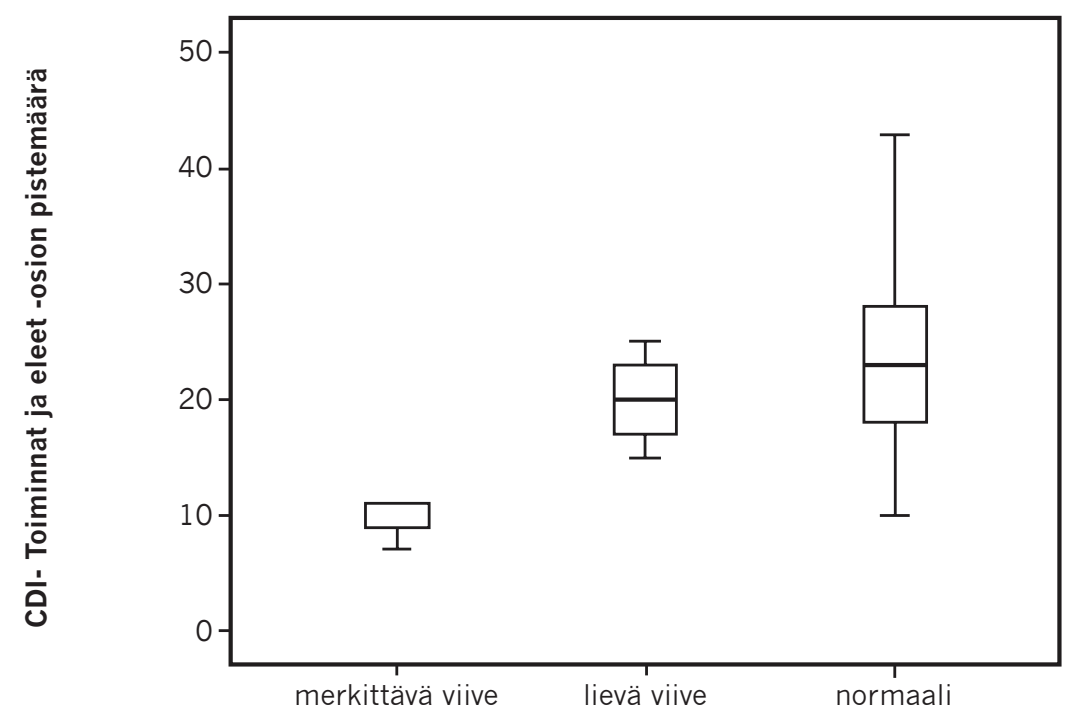

Bayley-III:n kognitiivinen taso

(5-7 SP, n = 4) ryhmään kahden vuoden iässä kuuluvat saivat ele- ja esinetoimintojen kehitystä kuvaavan osion kokonaispistemääräksi vuoden iässä keskimäärin 20 pistettä (kh 4, vv: 15-25). Keskoset, joilla oli kognitiivisessa suoriutumisessa merkittävää viivettä $(<5$ SP, $\mathrm{n}=3$ ) kahden vuoden korjatussa iässä, saivat CDI:n eleitä ja esinetoimintoja kartoittavasta osiosta vuoden korjatussa iässä keskimäärin 10 pistettä (kh 2, vv: 7-11).

\section{POHDINTA}

Tässä tutkimuksessa arvioitiin pikkukeskosena syntyneiden lasten ele-esinetoimintojen kehitystä vuoden korjatussa iässä sekä tämän kehityksen yhteyttä kognitiiviseen kehitykseen kahden vuoden korjatussa iässä. Ryhmätason keskiarvon perusteella tarkastellen pikkukeskosena syntyneiden lasten ele- ja esinetoimintojen kehitys oli kokonaisuutena arvioiden heikompaa kuin Varhaisen kommunikaation ja kielen kehityksen arviointimenetelmän normiaineistossa, vaikkakin eleiden omaksumisessa esiintyi suurta vaihtelua yksilöiden välillä. Noin kolmannes keskosista sijoittui vuoden korjatussa iässä ele-esinetoimintojen kehityksessään nk. huolirajan alle, kun täysiaikaisina syntyneiden lasten aineistossa lapsista noin $10 \%$ saa vastaavan tai pienemmän pistemäärän. Pikkukeskosten kognitiivinen kehitys oli kaksivuotiaana ryhmätasolla arvioiden vastaavaa kuin BayleyIII -testin normiaineistossa, mutta ryhmään kuului myös lapsia, joilla oli lievä tai huomattava kognitiivinen viive. Kaksivuotiaana kognitiivisesti tyypillisesti kehittyneet lapset olivat omaksuneet vuoden korjatussa iässä keskimääräisesti eniten eleitä, kun taas kognitiivisessa kehityksessään heikosti edenneet 
olivat vuoden iässä omaksuneet eleitä vähiten.

Pikkukeskosena syntyneiden lasten eleesinetoimintojen kehityksen keskiarvo oli pienempi kuin käytetyn menetelmän normiaineistossa vastaavassa ikäpisteessä. Tulos on yhdenmukainen aiemman pitkittäisseurantatutkimuksen (Stolt ym., 2014) tulosten kanssa, jossa 32 pikkukeskosen vuoden korjatun iän Varhaisen kommunikaation ja kielen kehityksen arviointimenetelmän Toiminnat ja Eleet -osion kokonaispistemäärän keskiarvo oli 20 (kh 9, vv 5-37) ja merkitsevästi heikompi kuin tutkimuksessa mukana olleiden 35 täysiaikaisena syntyneen verrokkilapsen. Kahden eri tutkimuksen rinnasteiset tulokset vahvistavat näkemystä siitä, että pikkukeskosena syntyneet lapset kehittyvät ryhmätasolla arvioiden hitaammin varhaisissa kielellis-kommunikatiivisissa taidoissa kuin täysiaikaisena syntyneet lapset (ks. myös Ortiz-Mantilla ym., 2008; Sansavini ym., 2011). Samansuuntaiset tulokset vahvistavat myös Varhaisen kommunikaation ja kielen kehityksen arviointimenetelmän Toiminnat ja eleet -version toimivuutta erotella toisistaan eleesinetoimintojen kehityksessään tyypillisesti ja heikosti etenevät pikkukeskoset. Tulosta tulkittaessa on kuitenkin tärkeää ottaa huomioon huomattava yksilöiden välinen kehityksellinen vaihtelu vuoden korjatussa iässä. Heikompaa ele-esinetoimintojen kehitystä ei siis voi yleistää koskemaan kaikkia pikkukeskosia - osa lapsista kehittyi ikätasonsa mukaisesti ja jopa sitä paremmin.

Varhaisten ele-esinetoimintojen kokonaispistemäärää tarkastellessa keskosryhmän lapsista noin kolmannes jäi Varhaisen kommunikaation ja kielen kehityksen arviointimenetelmän normiaineistossa nk. huolirajan alle. Ele-esinetoimintojen omaksuminen tapahtuu siis suuremmalla osalla pikkukeskosista selvästi hitaammin kuin täysiaikaisena syntyneillä lapsilla. Löydös on samansuuntainen kuin aiemmassa pitkittäisseuranta- tutkimuksessa (Stolt ym., 2014). Mainitussa tutkimuksessa vähäinen ele-esinetoimintojen hallinta vuoden korjatussa iässä myös ennakoi merkitsevästi heikkoa kielellistä kokonaistasoa kaksivuotiaana keskosaineistossa. Ensimmäisten kommunikoivien eleiden on ajateltu olevan osoitus lapsen kyvykkyydestä osallistua tavoitteelliseen kommunikointiin (Fenson ym., 2007) ja ensimmäisten leikkien olevan merkki jaetun tarkkaavaisuuden taidoista (Laakso, 2003). Havainto siitä, että pikkukeskoset omaksuivat ryhmätasolla arvioituna vähemmän varhaisia eleitä kuin täysiaikaisina syntyneet lapset, antaa tietoa pikkukeskosten tavoitteellisen kommunikoinnin kehityksestä (Stolt ym., 2014). Esinetoiminnot ovat osoitus lapsen kyvystä symboliseen kuvailuun, ja ne edellyttävät lapselta sekä motorisia että kognitiivisia taitoja (Iverson, 2010). Keskosilla on havaittu ryhmätasolla arvioiden vaikeuksia motoriikan ja kognition kehittymisessä (Bhutta ym., 2002; de Kieviet, Piek, Aarnoudse-Moens \& Ooserlaan, 2009), mikä voi osaltaan vaikuttaa negatiivisesti sosiaalisen vuorovaikutuksen tilanteisiin ja sitä kautta eleiden ja esinetoimintojen omaksumiseen. Kehityksen seurantaa tuleekin suositella silloin, kun lapsi omaksuu varhaisia ele-esinetoimintoja selvästi ikätovereitaan hitaammin (Lyytinen, 1999; Laakso ym., 2011).

Tutkimukseen osallistuneiden pikkukeskosten kognitiivinen kehitys oli ryhmätasolla arvioituna vastaavaa kuin ikäryhmän normiaineistossa. Tulos on samansuuntainen viimeaikaisen suomalaisen keskostutkimuksen kanssa (Munck ym., 2010). Sekä Munckin ym. (2010) tutkimuksessa että tässä aineistossa pikkukeskosten kognitiivinen kehitys on ryhmätasolla arvioiden hyvää verrattuna kansainvälisiin tutkimustuloksiin (Johnson, Wolke \& Marlow, 2008; Rose ym., 2009; Westera ym., 2008). Keskosten kognitiivisen kehityksen väliset erot eri maiden kesken voivat selittyä erilaisilla terveydenhoitojärjestel- 
millä sekä eri taustatekijöiden vaikutuksella (Munck ym., 2010). Keskosten kehitystä onkin tärkeää seurata alueellisesti, jotta saataisiin ajantasaista tietoa keskosten kehitysennusteesta. Edelleen, tässä tutkimuksessa noin $5 \%$ :lla pikkukeskosista esiintyi kognitiivisessa kehityksessä merkittävää viivettä (- 2 SD). Myös tämä tulos on samansuuntainen Munckin ym. (2010) tutkimustulosten kanssa, jossa 3,3 \% pikkukeskosista suoriutui kognitiivisesta asteikoista erittäin heikosti (Mental Development Index, MDI < 70 standardipistettä). Samansuuntainen tulos vahvistaa pikkukeskosten kognitiiviseen kehitykseen liittyvää löydöstä.

Pikkukeskosten ele-esinetoiminnot ja erityisesti ensimmäiset kommunikoivat eleet sekä varhaiset esinetoiminnot olivat merkitsevässä yhteydessä kognitiiviseen kehitykseen kahden vuoden korjatussa iässä. Juuri ensimmäisiä kommunikoivia eleitä ja varhaisia esinetoimintoja lapset olivat vuoden korjatussa iässä eniten omaksuneetkin. Ele-esinetoimintojen hallinta kertoo, miten lapsi ymmärtää syy-seuraussuhteita (Launonen, 2007) sekä, osaako lapsi kiinnittää huomiota ympäristönsä tapahtumiin, painaa toiminnot mieleensä ja toistaa ne omassa toiminnassaan (Capone \& McGregor, 2004; Iverson, 2010). Nämä taidot ennakoivat myös lapsen kognitiivista kehitystä. Tämä tutkimus on ensimmäinen, joka osoittaa varhaisen ele-esinetoimintojen kehityksen yhteyden myöhempään kognitiiviseen kehitykseen pikkukeskosena syntyneiden lasten aineistoissa. Tuloksia tarkastellessa tulee huomioida, että molemmat menetelmät, sekä Varhaisen kommunikaation ja kielen kehityksen arviointimenetelmä että Bayley-III -testi, sisältävät osioita, jotka mittaavat lapsen esinetoimintoja. Tämä voi selittää osaltaan varhaisten esinetoimintojen sekä kognitiivisen asteikon välistä yhteyttä. Tulosten luotettavuuden lisäämiseksi ele-esinetoimintojen ja kognitiivisen kehitystason arviointipisteitä olisi myös hyvä olla useampia, sillä lapset saattavat ottaa kehitysharppauksia eri ikäpisteissä (Määttä ym., 2012). Tuloksia tulkittaessa on hyvä huomioida myös se, että tässä tutkimuksessa varhaisten ele- ja esinetoimintojen ja myöhemmän kognitiivisen kehityksen välisen yhteyden tutkimiseen käytettiin korrelaatiokertoimia ja yhteyden kuvailua. Näin saatiin tietoa tarkasteltavien ilmiöiden välisestä yhteydestä, mutta ei varsinaisesti tietoa yhteyden suunnasta. Lisää tutkimusta keskosaineistossa aiheesta tarvitaan tulosten vertailun ja luotettavuuden lisäämiseksi, vaikka aiemmissa tutkimuksissa onkin havaittu varhaisten kommunikatiivisten ja myöhempien kognitiivisten taitojen välinen yhteys täysiaikaisina syntyneillä lapsilla (Laakso ym., 2011; Lyytinen, 1999).

Varhaisen kommunikaation ja kielen kehityksen arviointimenetelmän ele-esinetoimintoja kartoittavassa osiossa nk. huolirajan alittaneet ja tyypillisesti kehittyneet keskoset eivät eronneet toisistaan myöhemmässä kognitiivisessa kehityksessään. Tulos saattaa viitata siihen, ettei huolirajana ollut pistemäärä erotellut pikkukeskosia tarpeeksi hyvin silloin, kun haluttiin tarkastella erityisesti eleiden ja myöhemmän kognition välistä mahdollista yhteyttä. Tulos on päinvastainen Stoltin ym. (2014) tutkimuksen löydöksen kanssa, jossa sama pistemäärä erotteli hyvin myöhemmässä kielellisessä kehityksessä tyypillisesti ja heikosti kehittyvät lapset. Ero löydösten välillä voi viitata siihen, että ele- ja esinetoiminnot olisivat vahvemmin yhteydessä kielen kehitykseen kuin kognitiiviseen kehitykseen. Kuitenkin, tutkittaessa miten eri tavoin kognitiivisessa kehityksessään edenneet pikkukeskoset hallitsivat ele-esinetoimintoja vuotta aiemmin, havaittiin, että kognitiivisessa kehityksessään ikätasoaan vastaavasti edenneet pikkukeskoset olivat omaksuneet myös varhaisia ele- ja esinetoimintoja parhaiten. Vastaavasti kognitiivisessa kehityksessään ikätovereita hei- 
kommin edenneet olivat omaksuneet myös varhaisia ele-esinetoimintoja muita heikommin. Varhaisten eleiden ja esinetoimintojen omaksuminen edellyttää kielen tapaan kognitiivisia taitoja (Capone \& McGregor, 2004). Tämä saattaa selittää todettua varhaisten eleesinetoimintojen ja myöhemmän kognitiivisen kehityksen välistä yhteyttä.

Tämän tutkimuksen vahvuutena voidaan pitää pikkukeskosten vuoden pituista kliinistä seurantaa sekä kohtuullisen suurta pikkukeskosten aineistoa $(\mathrm{N}=57)$. Toisaalta, kohtuullisen suuresta otannan koosta huolimatta tutkittavien määrät jäivät pienehköiksi silloin, kun lapset jaettiin alaryhmiin. Tämän tutkimuksen vahvuutena oli myös se, että käytettiin tunnettuja varhaisen kehityksen arviointimenetelmiä, joita on mahdollista käyttää myös kliinisessä työssä. Verrokkiryhmän käyttö olisi kuitenkin vahvistanut löydöksiä. Tästä huolimatta tutkimuksessa käytetyt arviointimenetelmät olivat normitettuja, joten saatuja tuloksia pystyttiin peilaamaan arviointimenetelmien normipopulaatioiden tuloksiin.

\section{LOPUKSI}

Tämä tutkimus antoi tietoa pikkukeskosena syntyneiden lasten ele- ja esinetoimintojen kehityksestä vuoden korjatussa iässä sekä tämän kehityksen yhteydestä kognitiiviseen kehitykseen kahden vuoden korjatussa iässä. Pikkukeskoset olivat omaksuneet ryhmätasolla arvioiden vähemmän ele- ja esinetoimintoja kuin käytössä olleen menetelmän normiaineistoon kuuluvat täysiaikaisena syntyneet lapset, vaikkakin ele- ja esinetoimintojen omaksumisessa esiintyi huomattavaa vaihtelua ryhmän sisällä. Pikkukeskosten vuoden iässä hallitsemien ele- ja esinetoimintojen määrä oli merkitsevässä yhteydessä lasten kognitiiviseen kehitykseen kaksivuotiaana. Tätä uutta tutkimustietoa voidaan hyödyntää silloin, kun halutaan tunnistaa kognitiivisessa kehityksessä tukea tarvitsevat pikkukeskosena syntyneet lapset. Pikkukeskosten ele- ja esinetoimintojen kehitykseen kannattaa kiinnittää huomiota kliinisessä työssä, sillä se voi antaa tietoa pikkukeskosten kielen ja kognition kehityksestä.

\section{LÄHTEET}

Acredolo, L. \& Goodwyn, S. (1988). Symbolic gesturing in normal infants. Child Development, 59, 450-466.

Aylward, G. P. (2002). Cognitive and neuropsychological outcomes: More than IQ scores. Mental Retardation and Developmental Disabilities Research Reviews, 8, 234-240.

Bayley, N. (2006). BAYLEY-III. Bayley scales of infant and toddler development-käsikirja. Helsinki: Psykologien kustannus Oy.

Bayley, N. (1993). The Bayley Scales of Infant Development (2nd ed.). San Antonio, TX: Psychological Corporation.

Bhutta, A. T., Cleves, M. A., Casey, P. H., Cradock, M. M. \& Anand, K. J. (2002). Cognitive and behavioral outcomes of school-aged children who were born 71 preterm: A metaanalysis. The Journal of the American Medical Association, 288, 728-737.

Blackmon, L.R., Batton, D.G., Bell, E.F., Denson, S.E., Engle, W.A., Kanto, W.P., ym. (2004). Age terminology during the perinatal period. Pediatrics, 114, 1362-1264.

Bode, M. M., D'Eugenio, D. B., Forsyth, N., Coleman, J., Gross, C. R. \& Gross, S. J. (2009). Outcome of extreme prematurity: A prospective comparison of 2 regional cohorts born 20 years apart. Pediatrics, 124, 866-874.

Capone, N. \& McGregor, K. (2004). Gesture development: A review for clinical and research practices. Journal of Speech, Language and Hearing Research, 47, 173-186.

Caprici, O., Contaldo, A., Caselli, M. \& Volterra, V. (2005). From action to language through gesture: A longitudinal perspective. Gesture, 5 , 155-177.

De Kieviet, J. F., Piek, J. P., Aarnoudse-Moens, C. S. \& Oosterlaan, J. (2009). Motor development in very preterm and very low-birth- 
weight children from birth to adolescence. A meta-analysis. Journal of the American Medical Association, 302, 2235-2242.

Fenson, L., Marchman, V., Thal, D., Dale, P., Reznick, J. \& Bates, E. (2007). MacArthur-Bates communicative development inventories. User's guide and technical manual $-2^{\text {nd }}$ edition. Baltimore: Paul H. Brookes Publishing Co.

Fenson, L., Dale, P. S., Reznick, J. S., Bates, E., Thal, D. J. \& Pethick, S. J. (1994). Variability in early communicative development. Monographs of the Society for Research in Child Development, 59, 1-173.

Goldin-Meadow, S. (2009). From gesture to word. Teoksessa E. L. Bavin (toim.), The Cambridge handbook of child language (s. 145-160). Cambridge: Cambridge University Press.

Guidetti, M. \& Nicoladis, E. (2008). Introduction to special issue: Gestures and communicative development. First Language, 28, 107-115.

Hirsikorpi, H. (2015). Hyvin ennenaikaisena jal tai hyvin pienipainoisena syntyneiden lasten eleiden ja esinetoimintojen kehitys yksivuotiaana ja sen yhteys kognitiiviseen kehitykseen kaksivuotiaana. Pro gradu -tutkielma. Oulu yliopisto, humanistinen tiedekunta, logopedia.

Iverson, J. (2010). Developing language in a developing body: The relationship between motor development and language development. Journal of Child Language, 37, 229 - 261.

Iverson, J. \& Goldin-Meadow, S. (2005). Gesture paves the way for language development. Psychological Science, 16, 367-371.

Iverson, J., Capirci, O. \& Caselli, M. (1994). From communication to language in two modalities. Cognitive Development, 9, 23-43.

Johnson, S., Wolke, D. \& Marlow, N. (2008). Developmental assessment of preterm infants at 2 years: Validity of parent reports. Developmental Medicine \& Child Neurology, 50, 58-62.

Laakso, M.-L., Eklund, K. \& Poikkeus, A.-M. (2011). Esikko. Lapsen esikielellisen kommunikaation ja kielen ensikartoitus. Jyväskylä: Niilo Mäki Instituutti.

Laakso, M.-L. (2003). Esikielellinen vuorovaikutus ja kommunikointi. Teoksessa T. Siiskonen, T. Aro, T. Ahonen \& R. Ketonen (toim.), Joko sepubuu? Kielenkehityksen vaikeudet varhaislapsuudessa (s. 20-47). Jyväskylä: PS-kustannus.

Landry, S., Smith, K., Miller-Loncar, C. \& Swank,
P. (1997). Responsiveness and initiative: Two aspects of social competence. Infant Behavior and Development, 20, 259-262.

Launonen, K. (2007). Vuorovaikutus - kehitys, riskitja tukeminen kuntoutuksen keinoin. Helsinki: Kehitysvammaliitto.

Lyytinen, P. (1999). MCDI. Varhaisen kommunikaation ja kielen kehityksen arviointimenetelmä. Jyväskylä: Niilo Mäki Instituutti.

Munck, P., Niemi, P., Lapinleimu, H., Lehtonen, L., Haataja, L...the PIPARI study group. (2012). Stability of cognitive outcome from 2 to 5 years of age in very low birth weight children. Pediatrics, 129, 503-508.

Munck, P., Haataja, L., Maunu, J., Parkkola, R., Rikalainen, H., Lapinleimu, H...the PIPARI study group. (2010). Cognitive outcome at 2 years of age in Finnish infants with very low birth weight between 2001 and 2006. Acta Pediatrica, 99, 359-366.

Määttä, S., Laakso, M.-L., Tolvanen, A., Ahonen, T. \& Aro, T. (2012). Developmental trajectories of early communication skills. Journal of Speech, Language, and Hearing Research, 55, 1083-1096.

Ortiz-Mantilla, S., Choudhury, N., Leevers, H. \& Benasich, A. (2008). Understanding language and cognitive deficits in very low birth weight children. Developmental Psychobiology, 50, 107-126.

Rose, J., Butler, E. E., Lamont, L. E., Barnes, P. D., Atlas, S. W. \& Stevenson, D. K. (2009). Neonatal brain structure on MRI and diffusion tensor imaging, sex, and neurodevelopment in verylow-birthweight preterm children. Developmental Medicine \& Child Neurology, 51, 526-35.

Salonen, S., Munck. P. \& Korja, R. (2008). BayleyIII. Bayley Scales of Infant and Toddler Development -testin suomalaisen laitoksen käsikirja. Helsinki: Psykologien kustannus oy.

Sansavini, A. Guarini, A., Savini, S., Broccoli, S., Justice, L., Alessandroni, R. \& Faldella, G. (2011). Longitudinal trajectories of gestural and linguistic abilities in very preterm infants in the second year of life. Neuropsychologia, 49, 3677-3688.

Sansavini, A., Bello, A., Guarini, A., Savini, S., Stefanini, S. \& Caselli, M. (2010). Early development of gestures, object-related actions, word comprehension and word production, and their relationships in Italian infants: A longitudinal 
study. Gesture, 10, 52-85.

Stolt, S., Haataja, L., Lapinleimu, H. \& Lehtonen, L. (2008). Early lexical development of Finnish children - a longitudinal study. First Language, 28, 259-279.

Stolt, S, Mäkilä, A.-M., Matomäki, J., Lehtonen, L., Lapinleimu, H. \& Haataja, L. (2014). The development and predictive value of gestures in very-low-birth-weight children: A longitudinal study. International Journal of Speech-Language Pathology, 16, 121-131.

Stolt, S., Lind, A., Matomäki, J., Haataja, L., Lapinleimu, H. \& Lehtonen, L. (2016). Do the early development of gestures and receptive and expressive language predict language skills at five years of age in prematurely born very-lowbirth-weight children? Journal of Communication Disorders, 61, 16-28.

Suttora, C. \& Salerni, N. (2012). Gestural development and its relation to language acquisition in very preterm children. Infant Behavior \& Development, 35, 429-438.
Toome, L., Varendi, H., Männamaa, M., Vals, M.A., Tänavsuu, T. \& Kolk, A. (2013). Follow-up study of 2-year-olds born at very low gestational age in Estonia. Acta Pediatrica, 102, 300-307.

Vohr, B. R. (2010). Cognitive and functional outcomes of children born preterm. Teoksessa C. Nosarti, R. M. Murray \& M. Hack (toim.), Neurodevelopmental outcomes of preterm birth. From childhood to adulthood. (s. 141-163). Cambridge: Cambridge University Press.

Westera, J.J., Houtzager, B. A., Overdiek, B. \& van Wassenaer, A. G. (2008). Applying Dutch and US versions of the BSID-II in Dutch children born preterm leads to different outcomes. Developmental Medicine \& Child Neurology, 50, 445-449.

Özcaliskan, S. \& Goldin-Meadow, S. (2005). Gesture is at the cutting edge of early language development. Cognition, 96, B101-B113. 


\section{EARLY DEVELOPMENT OF GESTURES AND ITS ASSOCIATION WITH LATER COGNITIVE DEVELOPMENT IN PREMATURELY BORN VERY PRETERM AND/OR VERY LOW-BIRTH- WEIGHT CHILDREN}

Hannele Asumaniemi, University of Oulu and Coronaria Kuntoutuspalvelut

Petriina Munck, Turku University hospital and University of Helsinki

Helena Lapinleimu, Turku University hospital and University of Turku

Suvi Stolt, University of Helsinki

The development of early gestures in very preterm/very-low-birth-weight children (VP/ VLBW; born < 32 gestational age and/or birth weight $\leq 1500 \mathrm{~g}$ ) has not been studied intensively. The studies on the possible association between early gestures and later cognitive development in this group of children are missing, although this information would be clinically relevant. This study analyzed the development of gestures at 1;0 (corrected age), and the association between early gestures and cognitive skills at 2;0 (corrected age) in aroup of 57 VP/VLBW children. The data on gestures was gathered using the Finnish version of the MacArthur-Bates Communicative Development Inventory (FinCDI). The cognitive skills of the children were assessed using the Bayley Scales of Infant and Toddler Development 3rd edition (Bayley-III), Cognitive score. The mean value of the total gestures summary score of the FinCDI was lower than the one in the norming study of the FinCDI. Cognitive development of the VP/VLBW children, when measured at group level, was age appropriate. Early development of gestures correlated significantly and positively with later cognitive skills. This information can be used when identifying those children who need follow-up already at an early age.

Keywords: cognitive development, development of gestures, prematurely born, very-lowbirth-weight, very preterm 